\title{
MALÎ SONUÇLU BİR İDARÎ YAPTIRIM ÖRNEĞİ: KAMU HARCAMA IHHALESINE KATILMAKTAN YASAKLANMA
}

\author{
An Example of Administrative Sanctions with Fiscal Consequences: \\ Prohibition from Participating to Public Tender
}

Dr. Aziz TAŞDELEN

\section{GİRIŞ}

İdarelerin taraf olduğu ihale usulleri gelir elde etmeye veya harcama yapmaya ilişkin olabilmektedir. Bu bağlamda gelir elde edilmesine yönelik ihaleler Devlet İhale Kanunu'nda (DİK) ${ }^{1}$, mal ve hizmet alımları ile yapım işlerine ilişkin harcama usulleri Kamu İhale Kanunu'nda $(\mathrm{KIIK})^{2}$ ve bu ihalelerin sözleşme aşamasının kuralları da Kamu İhale Sözleşmeleri Kanunu'nda (Kİ́SK) ${ }^{3}$ düzenlenmektedir. Bu çalışma kamu harcama ihalelerini konu alması nedeniyle, gelir elde etmeye yönelik kamu ihalelerinden yasaklanma konumuz dışında kalmaktadır (DİK m.83,84).

Kamu harcama ihalesine katılmaktan yasaklama, kısaca ihaleyi yapan idarenin ihaleye katılanları ihale sürecinden dışlamasını ifade etmektedir. İlk bakışta basit bir olay gibi görünmekle birlikte, yasal koşulların gerçekleşmesiyle idare tarafından verilen "ihaleye katılmaktan yasaklama

* Akdeniz Üniversitesi Hukuk Fakültesi, Malî Hukuk Doçenti.

${ }^{1} 2886$ sayılı Devlet İhale Kanunu (RG.10.09.1983-18161).

${ }^{2} 4734$ sayılı Kamu İhale Kanunu (RG. 22.01.2002-24648).

${ }^{3} 4735$ sayı1lı Kamu İhale Sözleşmeleri Kanunu (RG. 23.01.2002-24648). 
kararı", yenilik doğuran, icraî bir idarî işlem olarak ortaya çıkmaktadır. Çünkü böyle bir işlem ile kamu ekonomisinden piyasa ekonomisine doğru bir ödeneğin harcanarak aktarılması niteliğindeki ihale ve bu ihale sonucunda başlayan sözleşme sürecinde; mal, hizmet ve yapım işi arzedenlerin hakları temelinden etkilenmekte ve ihale isteklilerinin ihalelere katılma hakları bir süreliğine ellerinden alınmaktadır ${ }^{4}$. Diğer bir ifadeyle bu karar ile bir yandan ihaleye düzenine katılan kişi ekonomik bir yarardan yoksun birakılmakta, diğer yandan kamu harcama ihalesi düzeni korunmaktadır. İhale düzeninin korunması ihale ilkelerine uygunluk, idarenin zarara uğramaması, işlerin zamanında ve düzenli yapılması ile anlam kazanmaktadır ${ }^{5}$. Bu özelliği dolayısıyladır ki, ihaleden yasaklama kararının verilebilmesi için, ihale sürecine katılan kişilerin en azından bir kabahatinin olması gerekir. Herhangi bir kabahati olmadan bu kişilerin ihale sürecinden dışlanması rekabete dayalı ihale düzenini ve katılımcılara eşit davranılması ilkelerini zedeleyici niteliktedir. Tabiî ki, hukuksal yollar katılımcılar için güvence oluşturmaktadır. İdarenin ihale sürecine katılan kişiyi ihaleye katılmaktan yasaklaması (KİK m.58) ile sözleşme sürecinde yer alan yükleniciyi ihaleye katılmaktan yasaklaması (KİSK m.26) ayrı yasalarda düzenlenmektedir.

$\mathrm{Bu}$ bağlamda idare, ihale aşamasına özgü bazı işlemler yapmaktadır: Bunlardan bir kısmı tekliflerin reddedilmesi (KİK m.37) veya bütün tekliflerin reddedilerek ihalenin iptal edilmesi (KIK m.39) gibi sadece "idarî" niteliktedir. Bir kısmı da kabahate konu olan ihale ile birlikte aynı idarenin diğer ihalelerine de katılmanın önlenmesi (KİK m.58/III ) gibi "ihtiyatî tedbir" niteliğindedir ki, bu durumda, kişinin ihaleye katılma hakkı o ihale ve o idarenin diğer ihaleleri açısından ihtiyaten askıya alınmaktadır (KK m.19). Konumuzu oluşturan ihaleye katılmaktan yasaklanma (KİK m.58/I) ve sözleşme yapmaya yanaşmayan müteahhit aleyhine ayrıca teminatın da idareye gelir kaydedilmesine (KİK m.44) yönelik bir "idarî yaptırım kararı" alınmaktadır. Sözleşme aşamasında da ihaleye katılmaktan yasaklama kararı verilebilmektedir. Yine, ihaleye ve edimin ifasına fesat karıştırılması nedeniyle suçlular (ihaleye katılanlar ve onlarla birlikte hareket

\footnotetext{
${ }^{4}$ Ekonomik alanda kamu düzeninin korunması başkaca kanunların olduğu gibi KK'nun da amaçları arasındadır. Bu konuları düzenleyen kanunlar gücünü, devletin Anayasada yer alan ekonomiyi düzenleme görevinden almaktadırlar (Any m.167). Bu bağlamda mal ve hizmet piyasalarının sağlıklı ve düzenli işlemesini sağlayıcı ve geliştirirci tedbirlerin alınması devletin görevleri arasındadır. Bu amacı gerçekleștirebilmek için düzenleyici ve denetleyici kurum olan Kamu İhale Kurumu kurulmuş, bu kuruma idarî alanda düzenleme yapma yetkisi verilmiștir. Diğer bir ifade ile, kamuda mal ve hizmet alımları ile yapım iși, bağımsız idarî otorite örneği olan Kamu İhale Kurumu tarafından düzenlenmekte, denetlenmekte ve ihale sürecindeki uyuşmazlıklarına idarî aşamada çözüm getirilmektedir. Bununla birlikte diğer bağımsız idarî otoritelerde idarî yaptırım uygulama yetkisi bulunduğu halde, Kamu İhale Kurumu'nun ihale sürecinde işlenen kabahatler karşısında idarî yaptırım uygulama yetkisi bulunmamaktadır. İdari yaptırım türü olan ihaleden yasaklamayı ancak ihaleyi yapan idare karar verebilmektedir. Bu da, Kamu İhale Kurumunu diğer bağımsız idarî otoritelerden ayıran bir özellik olarak görülmektedir.

${ }^{5}$ KİK' nun 58 nci maddesi ile KİSK' nun 26 ncı maddelerinin gerekçesi.
} 
edenler) yargılanmakta ve hürriyeti bağlayıcı cezalar verilebilmektedir (TCK m.235, 236) ${ }^{6}$.

Kabahatler Kanunu (KK) bazı kabahat türleri ile birlikte kabahatlerin tüm genel kurallarını düzenlediği için, bu yönüyle bir "genel kanun" niteliğindedir". İhaleye katılmaktan yasaklanma kabahati için de durum böyledir. Belli bir süre öngörülmemekle birlikte, zaman içerisinde genel kanuna uyumu sağlanıncaya kadar, kabahatleri düzenleyen özel kanunların kuralları saklı tutulmaktadır. Burada saklı tutulan kurallar, KK ile uyum göstermeyenlerdir. Bununla birlikte KK ile yeni düzenlenen ve özel kabahatlere de uygulanabilecek bazı kurallar da bulunmaktadır. Bu çalışmada kabahatler ve onlara uygulanan yaptırımlara ilişkin genel kurallar bakımından KİK ile KİSK' nun uyumlu olup olmadığ inceleme konusu edilmektedir.

\section{HUKUKÎ NITTELIK}

Öyleyse ihaleden yasaklanmanın hukuki niteliği nedir? Kabahatler Kanunu'na (KK) göre kabahat, kanunun bir idarî yaptırım öngördüğü haksızlıktır (KK m.2/I) ${ }^{8}$. Buradaki haksızlığın suç niteliğinde olmadığına, salt kabahat niteliğinde olduğuna özellikle dikkat etmek gerekmektedir. Bilindiği gibi, suç niteliğinde olan haksızlıklara cezaî yaptırım uygulanmakta; oysa kabahat niteliğindeki haksızlıklara sadece idarî yaptırımlar uygulanabilmektedir ${ }^{9}$. Her iki yaptırımın da amacı hukuka aykırı

${ }^{6}$ KİK'nun 59 ve KİSK'nun 27 nci maddelerine göre ihaleye katılan isteklilerin ihale aşamasına ait (KÍK m.17) fiilleri ile yüklenicilerin sözleşme aşamasına ait (KISSK m.25) fiilleri, taahhüt tamamlandıktan sonra ve hatta kabul işlemi yapıldıktan sonra tespit edilse bile TCK hükümlerine göre soruşturulması gerekmektedir.

${ }^{7} 5326$ say1l Kabahatler Kanunu (RG. 31.03.2005-Mük. 25772)

8 Önceden ceza hukuku içerisinde düzenlenen "kabahatler" ile idare hukuku ile ceza hukukunun ortak noktasını oluşturan "idarî kabahat" ifadeleri yerine, kanundaki yeni şekliyle, yani sadece "kabahat" ve "idarî ceza" yerine "idarî yaptırım" kavramlarını kullanmak uygun olacaktır. Yine, KK'nun gerekçesinde, kabahatlerde hukuka aykırı olmakla birlikte, suçlardan farklı olarak hukuka aykırılığın "haksızlık" içeriği esas alındığından idari kabahatin "haksızlık" olduğu belirtilmektedir. Bu nedenle "hukuka aykırılık" niteliği çalışmada "haksızlık" kavramı ile ifade edilmektedir. Suçlarla kabahatler arasında nitelik farkı bulunmadığı, suçların kabahatlere göre daha ă̆ır suçlar olması nedeniyle aralarında nicelik farkı bulunduğu anlaşılmaktadır (Demirtaş, s.174; Mahmutoğlu, Fatih Selami: Kabahatleri Suç Olmaktan Çıkarma Eğilimi ve Düzene Aykırılıklar Hukukunda (İdari Ceza Hukukunda) Yaptırım Rejimi, Kazancı Kitap Ticaret A.Ş., İstanbul 1995, s.93; Kabahatler Kanunun gerekçesi, m.2). Bu fark nedeniyledir ki, kabahatlere idarî yaptırımlar idare tarafından idarî usullerle uygulanabilmektedir (Bkz. Gölcüklü, Feyyaz: "Idarî Ceza Hukuku" ve Anlamı, AÜSBFD, C.XVIII, Haziran 1963, No:2, (Gölcüklü,I), s.131, 135; Hafızoğulları, Zeki: Ceza Normu, Normatif Bir Yapı Olarak Ceza Hukuku Düzeni, Us-A Yayıncılık Şirketi, 2. Bask1, Ankara 1996, s.217; İçel, Kayıhan-Donay, Süheyl: Karşılaştırmalı ve Uygulamalı Ceza Hukuku, Genel Kısım, 1. Kitap, 4. Bası, Beta Basım Yayım Dağıtım A.Ş., İstanbul 2005, s.32).

${ }^{9}$ İdarî yaptırım, idare içindeki makam ve mercilerin idarî işlem niteliğindeki kararları şeklinde tanımlanmaktadır (Bkz. Oğurlu, Yücel, İdarî Yaptırımlar Karşısında Yargısal Korunma, Seçkin Yayınevi, Ankara 2000, s.28; Özay, İl Han: İdarî Yaptırımlar, İstanbul 
bir fiil ile bozulan kamu düzenini korumak ve faile bir yaptırım türü uygulanmasıdır. Suç için öngörülen hürriyeti bağlayıcı ve para cezaları hukuka aykırı fiil sahibine yönelik daha ağır yaptırımlardır; kabahatlere ise bu kadar ağır yaptırımların uygulanmaması genel ilkedir ${ }^{10}$. Bununla birlikte, kamu ihalesi isteklilerine uygulanan ihaleye katılmaktan yasaklanma kararı, bir anlamda potansiyel bir gelirin elde edilmesini önlediği için para cezası niteliği bulunmasa da maddî açıdan ağır sonuçlar doğurabilmektedir. Dolayısıyla kamu ihalesi isteklilerine uygulanan ihaleye katılmaktan yasaklanma kararı daha çok kişiler üzerinde ekonomik bir etki göstermekte, bu nedenle ihaleden dışlanabilmeleri için en azından ihale düzenini bozan bir kabahatlerinin bulunması zorunlu ve yeterli görülmektedir.

\section{FAIL}

Kabahatlerde fail tanımlanmamakla birlikte, kabahatin tanımından bir idarî yaptırımın uygulanmasına neden olan davranışta bulunan kişilerin (haksızlık yapanların) fail olabileceği anlaşılmaktadır (KK m.2). O halde kimler ihaleye katılmaktan yasaklanabilir? İhale düzenini bozan herkes ihaleden yasaklanabilir mi? Daha doğrusu ihale sürecinde sahip olunabilecek hangi sıfatla birlikte bu tür bir yasağa maruz kalınabilir? İhalenin hazırlık aşamasında ihale dokümanının satın alınmasıyla ileride istekli sıfatını kazanabilecek kişi tarafından ilk somut adım atılmaktadır. İlân ile başlayan ihaleye davete doküman alınarak bir bağ kurulmakta ve ihale sürecine girilmektedir. Çünkü, teklif verebilmek ve böylece istekli sıfatını kazanabilmek için öncelikle bir ihale dokümanının alınması gerekmektedir. Dolayısıyla ilk kez ihale düzeninin kuralları burada işlemeye başlamaktadır.

Üniversitesi Yayınları, İstanbul 1985, Yaptırımlar, s.40, 143); İdarî ceza hukuku ise, toplum düzenini bozan davranışlar ve bu davranışlara ilişkin yaptırımları ve idarenin usulüne ilişkin kuralları düzenleyen bir bilim dalı şeklinde tanımlanmaktadır (Bkz. Mahmutoğlu, s.54, 101, 123; İçel-Donay, s.31; Oğurlu, 28 vd.).

${ }^{10}$ Ceza hukukunda yaşanan son değişikliklerle, kabahatler ceza kanunundan ayrılmıştır. Önceden suçlar dışında kalan kabahatler, ceza hukuku içerisinde ve bazı idarî yasalarda dağınık bir şekilde yer almaktaydılar. Bu nedenle genellikle kabahatler ceza hukuku, idarî yaptırımlar ise idarî ceza hukuku içerisinde değerlendirilmekteydi. Gerek ceza hukuku gerekse idare hukuku kapsamında idarenin haksız bulduğu eylemlerin idarî yaptırıma bağlanarak "kabahat" şeklinde tek bir kavram ile düzenlenmesi, ülkemizdeki yeni suç politikasının bir sonucudur. Böylece idarî kabahatlere yönelik genel hükümler de, tüm kabahatleri kapsar şekilde Kabahatler Kanunu (KK) ile düzenlenmektedir. Başka ülkelerde önceden başlamış olan kabahatleri dar anlamda suç olmaktan çıkarma eğilimi, bunların düzene aykırılık fiilleri olarak düzenlenmesi politikası, böylece ülkemizde de gerçekleşmektedir (Bu yöndeki çalışmalar için bkz. Demirtaş, Timur: Ceza Hukuku Genel Hükümler, Seçkin Yayınları, Ankara 2002, s.178; Bkz. İçel, Kayıhan: "İdarî Ceza Hukuku ve Kabahatleri Suç Olmaktan Çıkarma Eğilimi”, IÜHHFM, 1984, S.1-4, (İdarî Ceza), s.119; İçel-Donay, s.32; Ayrıntılı bilgi için bkz. Mahmutoğlu, s.13 vd.,50). Kabahatler Kanunu Tasarısı'nın gerekçesinde bu husus hukuk birliğinin sağlanması için "özel kanunlarda sadece kabahat türünden fiillerin tanımlanması ve bu fiiller karşıllı̆̆ında öngörülen idari yaptırımların belirtilmesiyle yetinilmesi” istenilmekte, genel kuralların özel kanunlardaki kabahatler için de uygulanması gerektiği belirtilmektedir (KK m.3). 
Bundan sonra, son başvuru anına kadar teklif verip vermemek ihale dokümanını satın almış kişi için seçimlik bir haktır. Teklifte bulunup da ihaleyi kazanan istekli bu andan sonra "yüklenici" sıfatını almaktadır. İhaleye katılmaktan yasaklanma kararı için en azında ihale dokümanına sahip olunmasını gerektirmektedir. Ki, bundan sonra doküman alan başkalarının ihaleye katılmasının engellenmesi, tehdit edilmesi, onlarla anlaşma yapılması veya ihaleyi kazandığında sözleşme yapmaya yanaşılmaması gibi fiilleri işleyebilmesi mümkün olsun. Sözleşme aşamasında ise sadece sözleşmeye taraf olan yüklenici, sözleşmenin uygulanmasında ihale düzenini bozucu davranış içerisinde olabilecektir. Sonuç olarak bir ihale sürecine doküman alarak teklif sunma arzusunu ortaya koyan kişiler, ihaleye teklif sunanlar, ihaleyi kazananlar ve sözleşmeye taraf olarak sözleşmeyi uygulama yükümlülüğü altına giren yükleniciler fail olabilmektedir. Harcama ihalesi düzeni, ihale düzeninde haksızlık yapan bu kişilere karşı korunmakta, bu nedenle katılmalarına yasak konulmaktadır.

\section{HUKUKÎ YARAR}

Çok kapsamlı olan kamu düzeni kavramı içerisinde kalan kabahatlerin mağduru "herkes" tir" ${ }^{11}$. Bu nedenle hukuksal düzen soyut bir varlık olan herkes için korunmaktadır: Konumuzu oluşturan kamu harcama ihalesi öncesinde bütçede somut bir ödenek şeklinde gösterilen kamu kaynağı, harcama yapacak bir idareye özgülenmekte ve bu idarenin herkese yönelik hizmetleri için harcanmaktadır. İşte ödeneğin özgülendiği bu idarenin uygulayacağı ihale kurallarının ihlâli nedeniyle ihale düzeni bozulmakta, dolayısiyla hem somut olarak ihale sahibi idarenin hem de soyut olarak herkesin hakları bundan zarar görebilmektedir. Diğer bir ifadeyle maddî anlamda kamunun malvarlığı (idareye ayrılan ödenek) ve usul açısından harcamaya ilişkin kurallar düzeni zarar görmektedir ${ }^{12}$. Ne var ki, kamu ihale sürecinde işlenen kabahatlerin mağduru sadece idare ve idarenin temsil ettiği soyut nitelikteki herkesten ibaret değildir. Gerçi kamu ihalesini kabahat işleyerek üzerine alan bir ihale isteklisi, hukuka uygun olmayan koşullarla bir iş yaparak çoğu kez herkesi maddî zarara uğratmakta ve bunun sonucunda toplumun elde edebileceği en yüksek yararın gerçekleşmesini engellemektedir. Başka bir deyişle; herkese ait olan ve herkes için harcanan kamu kaynaklarıyla yaratılabilecek değerleri azaltmaktadır. Fakat böyle bir fiil ile en çok mağdur olan kişi, gerçekte ihaleyi kazanma koşullarını taşıdığı halde kazanamamış olan diğer ihale isteklileridir.

\footnotetext{
${ }^{11}$ Mahmutoğlu, s.92.

12 Devletin ekonomik çıkarlarının korunmakta olduğu yönündeki görüs için bkz. Artuk, Mehmet Emin-Gökcen, Ahmet-Yenidünya, Caner: Ceza Hukuku Özel Hükümler, Turhan Kitabevi, 6 Bas1, Ankara 2005, s.456.
} 


\section{IV. İHALEDEN YASAKLANMANIN UNSURLARI}

Kabahatler, KK'nunda ve kabahat normu taşıyan birçok özel kanunda düzenlenmektedir. Kanunda bir yandan bazı kabahatler düzenlenirken aynı zamanda kabahat hükmü taşıyan özel kanunlarında bulunduğunu kabul edilmektedir (KK m.3). İhaleye katılmaktan yasaklanma yaptırımı da bunlar arasındadır. İhale düzenine katılanların ihaleden yasaklanmasına neden olan fiilleri KİK' nun 11 nci ve 17 nci maddelerinde; bunlarla ilgili ihaleye katılmaktan yasaklama yaptırımı da aynı yasanın 58 nci maddesinde düzenlenmektedir. $\mathrm{Bu}$ maddeler birlikte ele alındığında ihale düzeninde haksızlık yaratan fiillerin iki ana başlık altında toplanabildiği görülmektedir: 1) ihale aşamasındaki kabahatler; 2) sözleşme hazırlığındaki kabahatler. İhalenin sözleşme aşamasında ihaleden yasaklanmaya neden olan fiiller ise KİSK'nun 25 nci maddesinde ve bu fiillerin ihlali nedeniyle ihaleden yasaklanma yaptırımı 26 ncı maddesinde düzenlenmektedir. Bu kurallar ihaleden katılmaktan yasaklanma yaptırımının "hukuksal nedeni"ni oluşturmaktadır. Bu fiiller ile tipleştirme yapılmıştır. İhale sürecine katılanların fiilleri emredici nitelik taşıyan bu kurallara uygun olması durumunda yaptırımla karşılaşacaktır. Öncelikle ihale sürecindeki sonra da sözleşme sürecindeki ihaleden yasaklanma nedenleri incelenecektir.

\section{A. MADDİ UNSURU}

\section{1. İhale Süreci}

\section{a. İhale Aşamasındaki Fiiller}

İhale aşamasındaki kabahatlerin başında "ihaleye fesat karıştırılması" gelmektedir. Bu fiil hem idarî yaptırımı olan kabahatler, hem de cezaî bir yaptırımı olan suçlar arasında sayılmaktadır. Ne var ki, "ihaleye fesat karıştırma" kanunda tanımlanmamaktadır. Bu kavramı daha açık bir duruma getirmek için "fesat karıştırma" deyiminin sözlük anlamından yola çıkılabilir. Fesat karıştırmak ortalığ 1 karıştırmaya çalışmak, insanları birbirlerine düşürecek işler yapmak anlamına gelmektedir ${ }^{13}$. Kanunda ise hile, vaat, tehdit, nüfuz kullanma, çıkar sağlama, anlaşma, irtikap, rüşvet ve başkaca yollara başvurma gibi fiiller fesat karıştırma biçimleri olarak sıralanmaktadır ${ }^{14}$. Bütün bu fiiller kamu düzenini bozma özellikleri

${ }^{13}$ Devellioğlu, Ferit; Osmanlıca-Türkçe Ansiklopedik Lûgat, Ankara 2002, s.262; Türk Dil Kurumu. Türkçe Sözlük, C.I, Ankara 1998, s.774.

${ }^{14} \mathrm{Bu}$ konuda suçlar bakımından yapılan açıklamalarda, sadece ihmalî veya icrâ̂ hareketin yapılması ile suç tamamlandığından ötürü "sırf hareket suçu" veya "sekli suç" denilmektedir (Bkz. Artuk-Gökcen-Yenidünya, s.465; Demirtaş, s.203; Gölcüklü, I, s.138; Soyaslan, Doğan: Teşebbüs Suçu, Kazancı Kitap Ticaret A.Ş., Ankara 1994, s.10-11; 
nedeniyle yasada haklı bir biçimde fesat karıştırma örnekleri olarak gösterilmektedir. Fesat karıştırma örnekleri sıralanırken yasada en son olarak “...başka yollarla...” gibi bir deyim de kullanılmakta, böylece fesat karıştırmanın ad belirtilerek verilen örneklerle sınırlı kalmamaktadır. Bundan da anlaşılmaktadır ki, ihalenin usulüne uygun tamamlanmasını engelleyen ve onun yeniden yapılmasını gerektiren her tür fiil fesat karıştırıcı sayılmaktadır.

İhale aşamasındaki kabahatlerin geri kalanlarının bir kısmı, "isteklileri tereddüde düşürülmesi ${ }^{15}$, isteklilerin ihaleye katılmalarının engellenmesi, isteklilere anlaşma teklifinde bulunulması ya da bir anlaşmaya teşvik edilmesi, rekabeti ya da ihale kararını etkileyici davranışlarda bulunulması" diye sıralanmaktadır. Bu kabahatlerin hepsi rekabetin oluşmasını önleyen fiillerin birer somut görünümüdür. Bunlar istekliler tarafından işlenebileceği gibi, onlarla birlikte hareket edenler tarafından da işlenebilmektedir. Bu fiillerden en azından birinin gerçekleşmesi durumunda ihaleden yasaklama kararının alınması kaçınılmaz olmaktadır.

İhale aşamasında kabahatlerden birisi de sahte belgeyle ilgili fiillerdir. Bunlar "sahte belge düzenlemek ve sahte belge kullanmak" diye adlandırılmaktadır. Sahte belge düzenlemek fiili, genellikle isteklilerden ihaleye katılım sırasında ihale ilânında istenen "ekonomik ve malî yeterlilik", "meslekî ve teknik yeterlik" belgeleri ile "teminat belgesi" üzerinde işlenebilmektedir. Bunlardan bir kısmı resmî belge, bir kısmı da özel belge niteliğindedir. Bu belgeler ister resmî, isterse özel olsun, sahte olarak düzenlendiklerinde kabahat oluşmaktadır. İsteklilerin teklif ekinde sundukları ve kendileri tarafından düzenlenmiş olan bu belgeler sahte belge düzenleme fiilini gerçekleştirmektedir. $\mathrm{Bu}$ da, ihaleye katılmaktan yasaklanma kararına dayanak oluşturmaktadır. İhale isteklisi kendisi sahte belge düzenlememiş, fakat başkalarının düzenlemiş olduğu sahte belgeleri ihale teklifi ekinde sunmuş ise, bu fiil sahte belge kullanma kabahatini oluşturacaktır. $\mathrm{Bu}$ durumda sahte belge düzenleyen kişi yalnızca cezaî yönden sorumlu tutulabilecek, ihale isteklisine uygulanan ihaleye katılmaktan yasaklanma kararı bu kişiye de uygulanamayacaktır.

İhale aşamasındaki kabahatlerden bir başkası "ihalede alternatif teklif kolaylığı dışında birden fazla teklif vermesi" dir. Birden fazla teklif vermek fiili, alternatif teklif verebilmesi dışında, ihalelerde bir isteklinin kendisi veya başkaları adına doğrudan veya dolaylı olarak, asaleten veya vekaleten birden fazla teklif vermesini belirtmektedir (KİK m.17/d). Burada amaç,

Soyaslan, Doğan: Ceza Hukuku Genel Hükümler, Yetkin Yayınları, 2. Bask1, Ankara 2003, (Soyaslan, Genel), s.228). Konumuz acısından ise ihale düzeninin korunmasına yönelik kabahatlerin de sırf hareket suçu niteliği taşıdıkları, kabahatin ayrıca netice kısmının bulunmadı $\breve{g}_{1}$ görülmektedir.

${ }^{15}$ İhaleye katılanların tereddüde düşüp düşmediklerinin takdirinin idare tarafından yapılması, sübjektif bir durum tespiti olduğundan oldukça zordur. Hatta diğer ihaleye katılanlar tarafından nasıl olup da tereddüde düşürülebilecekleri de belirsiz bir durumdur. 
isteklilerin birer teklif sunmalarıyla eşitlikçi ve rekabetçi ihale düzeninin korunmasıdır. İstisnaî olarak alternatif teklif sunulabilmesi, ancak, ihale ilânı ve ihale şartnamesinde belirtildiği takdirde kullanılabilecek bir haktır. Dolayısıyla, açıkça ihale dokümanında ve buna dayalı ilânda belirtilmesi koşuluyla alternatif teklif verilebilmektedir. Aksi davranış, ihale dişı kalınmasına neden olacağı gibi bir süre kamu harcama ihalesinden yasaklanmayı da gerektirmektedir. İki farklı teklif verme yasağı başkası adına verilen teklif ile teklifin dolaylı bir şekilde verilmesini de kapsamaktadır. İsteklinin aynı ihalede hem kendisinin ve hem de vekilinin teklif sunması, bu yasak kapsamındadır. Dolaylı teklif verilmesi ile neyin kastedildiği açık değildir. Bununla birlikte bir katılımonın hem kendisi adına hem de pay çokluğunu elinde bulundurduğu sermaye şirketi veya şahıs şirketi adına teklifte bulunması düşünülebilecek ilk durumdur. Ancak şu durumu ayırt etmek gerekmektedir: İki farklı tüzel kişi ayrı ayrı istekli sıfatını taşıdığında, bu tüzel kişiler adına bir vekilin ayrı teklifler sunması söz konusu yasağın çiğnenmesi anlamına gelmemektedir ${ }^{16}$.

İhale aşamasındaki kabahatlerin sonuncusu yasa gereği "ihaleye katılamayacağı belirtilenlerin ihaleye katılması" dır (KİK m.11, 58). İhale düzeninin korunması amacıyla, ihaleye katılması yasaklı olanların bir şekilde ihaleye katılmış olması, ihaleye katılmalarının yasaklanmasına karar verilmesini gerektirmektedir ${ }^{17}$. Hatta bu yasak KİK kapsamı dışında kalan ihalelere de etkili olmaktadır. Yani, işlemiş olan bir kabahat ile, yasaklama süresince, KİK'nun uygulanmasından istisna edilen idarelerin ihalelerini de kapsayacak şekilde karar verilmektedir (KİK m.3,11,58/I).

${ }^{16}$ Taşdelen, Aziz: Kamu Harcamaları Hukukunda İhale Süreci, Turhan Kitabevi, Ankara, 2004,s.156.

17 (KİK, m.11) Aşağıda sayılanlar doğrudan veya dolaylı veya alt yüklenici olarak, kendileri veya başkaları adına hiçbir şekilde ihalelere katılamazlar: a) Bu kanun ve diğer kanunlardaki hükümler gereğince geçici veya sürekli olarak kamu ihalelerine katılmaktan yasaklanmış olanlar ile 3713 sayılı Terörle Mücadele Kanunu kapsamına giren suçlardan ve organize suçlardan dolayı hükümlü bulunanlar, b) İlgili mercilerce hileli iflâs ettiğine karar verilenler, c) İhaleyi yapan idarenin ihale yetkilisi kişileri ile bu yetkiye sahip kurullarda görevli kişiler, d) İhaleyi yapan idarenin ihale konusu işlerle ilgili her türlü ihale işlemlerini hazırlamak, yürütmek, sonuçlandırmak ve onaylamakla görevli olanlar, e) (c ) ve (d) bentlerinde belirtilen şahısların eşleri ve üçüncü dereceye kadar kan ve ikinci derece kadar kayın hısımları ile evlatlıkları ve evlat edinenleri, f) (c ), (d) ve (e) bentlerinde belirtilenlerin ortakları ile şirketleri (bu kişilerin yönetim kurullarında görevli bulunmadıkları veya sermayesinin \%10 undan fazlasına sahip olmadıkları anonim şirketler hariç). İhale konusu işin danışmanlık hizmetlerini yapan yükleniciler bu işin ihalesine katılamazlar. Aynı şekilde, ihale konusu işin yüklenicileri de o işin danışmanlık hizmeti ihalelerine katılamazlar. Bu yasaklar, bunların ortaklık ve yönetim ilisskisi olan şirketler ile bu şirketlerin sermayesinin yarısından fazlasına sahip oldukları şirketleri için de geçerlidir. (Değişik: 30.07.2003-4964 sayılı Kanun,m.8) İhaleyi yapan idare bünyesinde bulunan veya idare ile her ne amaçla kurulmuş olursa olsun vakıf, dernek, birlik, sandık gibi kuruluşlar ile bu kuruluşların ortak oldukları şirketler bu idarelerin ihalelerine katılamazlar. şeklinde sayılmaktadır. 


\section{b. Sözleşme Hazırlığındaki Fiiller}

Sözleşmeye hazırlık aşamasına özgü tek kabahat; lehine ihale kararı verilen isteklinin mücbir sebepler dışında "kamu ihale sözleşmesini yapmaya yanaşmama"sıdır. Bu fiil, ihmalî bir davranış niteliğindedir. İhaleyi kazananın süresinde bir sözleşme yapma ve imza atma yükümlülüğü bulunmaktadır. Bu yükümlülüğünü yerine getirmediğinde de icrâ̂ bir davranış eksikliğine dayalı bir kabahat oluşmaktadır (KK m.7). Kabahatin oluşmasını engelleyen tek koşul, süresinde bir sözleşme yapma eylemini imkansız kılan bir mücbir sebebin varlığıdır. Kanunda bu nitelikteki mücbir sebeplerin neler olduğu belirtilmemektedir. Bununla birlikte, bu sebep isteklinin iradesi dışında gerçekleşen ve sözleşme yapabilmesini engelleyici niteliğe sahiptir ${ }^{18}$ : Deprem, sel baskını, kaçırılma, ağır hastalık gibi. Mücbir sebepler her somut olayda idarece takdir edilebilecek olaylardir ${ }^{19}$. Bu bağlamda isteklinin iradesi dışında sözleşme yapmasına engel durumun bulunup bulunmadığı hususu isteklinin sunduğu belge ve bilgilere göre değerlendirilecektir.

İhale sürecinin normal sonucu, ihale kararında belirlenen istekli ile bir sözleşme yapılmasıdır; bu aynı zamanda idare ve istekli için yükümlülüktür (KİK m.44/I, 46) ${ }^{20}$. Bu bağlamda hem isteklinin hem de idarenin onaylanan ihale kararı üzerine sözleşmeyi yapma ödevleri (yükümlülükleri) doğmaktadır. Bu ödevin yapılmasından sonra, ekonomik açıdan en avantajlı olan birinci ve ikinci isteklinin geçici teminatları iade edilebilmektedir. İsteklinin kendisine gönderilen sözleşmeye davet mektubunda belirtilen sürede kesin teminatı teslim ederek sözleşmeyi imzalamaması durumunda ise başka bir işleme gerek kalmaksızın ekonomik açıdan en avantajlı birinci teklifin geçici teminatı gelir kaydedilmektedir (KİK m.44/II). Diğer bir anlatımla, ihale üzerinde kalan istekli, teminatını kaybetmek istemiyorsa tanınan süre içinde kesin teminatı yatırarak sözleşmeyi imzalamak zorundadır ${ }^{21}$. Aksi halde, idare, ekonomik açıdan ikinci en avantajlı teklifi uygun görerek sözleşme imzalayabilecektir. Bunun için ikinci teklif sahibine de on gün içinde kesin teminatı vermesi ve sözleşme yapması amaciyla sözleşmeye davet mektubu gönderilmektedir (KİK m.42, 44/II). Bu isteklinin de sözleşme imzalamaması durumunda geçici teminatı gelir kaydedilmektedir. Böylece sözleşmeye davet edilebilecek başka teklif sahibinin kalmaması nedeniyle ihale kararının icra edilebilme özelliğini ortadan kalkmaktadır. Sözleşmeye yanaşmayan birinci ve ikinci ekonomik

\footnotetext{
${ }^{18}$ Demirtaş, s.269.

${ }^{19}$ Danıştay önceki uygulama dönemine ilişkin bir kararında; DİK'nun 84 ncü maddesine göre, sözleşme yapmayan isteklinin engel neden olarak asgarî ücretteki artıșa dayanamayacağına, yani asgari ücret artışlarının mücbir sebep sayılamayacağına karar vermiştir (Dan. 10 D. 11.03.1991 T. 1988/607 E, 1991/871 K. Danıştay Dergisi, S. 82-83).

${ }^{20}$ Özay, İl Han: Gün Işı̆̆ında Yönetim, Alfa Yayınları, İstanbul 2002, (Özay, Yönetim), s.455.

${ }^{21}$ Gözler, Kemal: İdare Hukuku, C.II, Ekin Kitabevi, Bursa 2003, s.111.
} 
açıdan en avantajlı teklif sahipleri için öngörülen yaptırım, ihaleye katılmalarının yasaklanmasıdır.

Mücbir sebepler dışında sözleşme yapma yükümlülüğünü yerine getirmeye yanaşmayan isteklilerin ihaleye katılmalarının yasaklanması kararı yanında, ayrıca geçici teminatları da idareye gelir kaydedilmektedir (KİK m.44, 58/I). Bu teminat, eğer sözleşme yapılsaydı kesin teminat ile değiştirilecekti. Sözleşme yapmaya yanaşılmaması bunun iadesini önlemektedir. Sözleşme yapmaya yanaşmama fiilinin konusu bir yandan sözleşmenin yapılması iken diğer taraftan buna bağlı geçici teminatın kesin teminatla değiştirilmesini de kapsamaktadır. Geçici teminatın (mülkiyetinin) iade edilmeyerek idarede alıkonulması KK' da ayrı bir yaptırım türü olan "mülkiyetin kamuya geçirilmesi” anlamını taşımamaktadır (KK m.18). Bu tür işlemde mülkiyetin kamuya geçirilebilmesi için ortada kabahate konu olan bir eşya bulunmalıdır. Oysa teminat kabahatin işlenmesinden önce yasal olarak yatırılan bir güvence bulunmaktadır; idarenin zararının karşılanması amacını taşımaktadır. Teminatın gelir kaydedilmesi işlemi de idarî işlem niteliğindedir. Sonuç olarak sözleşme yapmaya yanaşmama fiilinin sonucunda hem ihaleye katılmaktan yasaklanma ve hem de geçici teminatın gelir kaydedilmesi yaptırımı uygulanmaktadır.

\section{Sözleşme Süreci}

Sözleşme uygulaması aşamasında işlenebilecek kabahatler yedi bentten oluşmakta, bunlardan ilk ikisi aynen KİK'nunda olduğu gibi, hile, vaat, tehdit, nüfuz kullanma, çıkar sağlama, anlaşma, irtikap, rüşvet suretiyle ve başka yollarla sözleşmeye ilişkin işlemlere fesat karıştırmak ve sahte belge düzenlemek ve kullanmak şeklinde belirtilmektedir (KİSK m.25/I,a,b). Diğer kabahatler ise özellikle sözleşmenin uygulanması aşamasına özgü özellik göstermektedirler. Bunlar daha çok Borçlar Kanunu'nun kurallarının da göz önünde bulundurulduğu kabahatlerdir (KİSK m.36). Bunlardan ilki edimin ayıplı ifasına ilişkindir. Fiiller yüklenicinin hileli malzeme, araç veya usul kullanılması, fen ve sanat kurallarına aykırılık, eksik, hatalı veya kusurlu inşaat yapılması şeklinde belirtildiğinden bazılarının sadece yapım işine özgü bazılarının da mal ve hizmet teslimine özgü olduğu görülmektedir. Dikkat edilirse burada ihale dokümanına göre düzenlenen sözleşme kuralları önem kazanmaktadır (KİSK m.4). Yüklenicinin ayıplı ifası ile idarenin zarara uğrayacağı açıktır. Bununla birlikte diğer bir bentte "taahhüdü yerine getirirken idareye zarar verilmesi" de ihaleden yasaklanma nedeni olarak sayılmaktadır. İdarenin zarara uğratılması nedenler sayıca sınırlandırılamayacak ölçüdedir. Bu nedenlerin ortak özelliği, idarenin miktar olarak hesaplanabilir bir zarara uğramasıdır ${ }^{22}$. Hatta yüklenicinin

${ }^{22}$ Bkz. Donay, Süheyl-Kaşıkçı, Mahmut: 5237 Sayılı Türk Ceza Kanunu, Vedat Kitapçılık, İstanbul 2004, s.307. 
edimleri ayıplı olmamasına rağmen işin zamanında teslim edilmemesi de, başka bir bentte sayılmakla beraber, bu kapsamda değerlendirilebilir. Fakat başka bir bentte sayılmakta olduğundan, bu bendi KİSK'nun 25 nci maddesinde özel olarak sayılmayan ve fakat idarenin zararına olabilecek fiiller şeklinde anlamak daha uygun olacaktır. Diğer bir kabahat fiili yüklenicinin edimini ifa ederken bilgi ve deneyimlerini idarenin zararına kullanmasıdır. İşin teknik standartlara uygun yapılması da bu kapsamdadır. Yine ihale sürecine danışmanlık hizmeti sunanların görevleri nedeniyle yüklenicilerin işleri, işlemleri, teknik ve malî yönlerine ilişkin gizli kalması gereken bilgi ve belgelerini kendileri veya başkaları yararına açıklamaları kabahat sayılmaktadır (KİSK m.25/I,e). Sözleşme gereği işin süresinde yerine getirilmesi sözleşmenin normal sonucudur. Bununla birlikte her zaman sözleşmeden doğan yükümlülükler tam zamanında yerine getirilemeyebilir. Bu durumda idarî yaptırımdan yükleniciyi kurtaran sadece mücbir sebepler olmaktadır (KİSK m.25/I,f) ${ }^{23}$.

Kamu ihale sözleşmelerinde kural ihaleyi kazanan istekli ile sözleşme yapılması ve bu tespit edilen yüklenicinin bizzat kendisi tarafından ifasıdır. İstinaî durumlar sayılan "zorunlu nedenlerle" ve ihale yetkilisinin yazılı izni ile işin bir başkasına devri mümkün olabilmektedir. Devir işleminin ön koşulu, devralacak yüklenicinin başlangıçtaki ihale koşullarını taşıyor olmasıdır; bu şekilde sözleşmenin bir başkasına devrinde kısıtlayıcı kurallar getirilmektedir ${ }^{24}$. Bu durumlarda sözleşmeyi devreden yüklenicinin üç yıl için başka sözleşmelerini devredebilmesi imkânı ortadan kalkmaktadır. Böylece izinsiz sözleşme devirleri ihaleye katılmaktan yasaklanma yaptırımı ile karşılaşmaktadır (KİSK m.16).

\section{B. MANEVI UNSURU}

Bir suçun işlenmiş sayılması için, genel olarak failin kastlı veya taksirli hareket etmiş olması aranmaktadır. Kabahatler için de aynı manevi unsurlar kabul edilmektedir (KK m.9) ${ }^{25}$. Kabahatlerde kasit bulunmasa bile manevi unsur açısından sadece taksirin bulunması her halde yeterli kabul edilmektedir ${ }^{26}$. Bu da, suçlar ile kabahatler arasındaki önemli farklardandır.

İsteklilerin tacir sıfatını taşımaları nedeniyle ihale düzenine vakıf oldukları (basiretli oldukları) ve bunun sonucunda da yukarıda sayılan

${ }^{23}$ KİSK'nun 10 ncu maddesine göre mücbir sebep sayılabilecek haller: 1) doğal afetler, 2) kanuni grev, 3) genel salgın hastalık, 4) genel ve kısmî seferberlik ilânı, 5) gerektiğinde kurum tarafından belirlenecek bezeri diğer haller, şeklinde örnek olarak sayılmaktadır.

${ }^{24}$ Küçükgüngör, Erkan-Akipek, Şebnem: "Kamu İhale Sözleşmeleri”, Malî Hukuk, Yıl 8, 2003, S.103, s.49.

${ }^{25}$ Önceki TCK'nun 45 nci maddesi gereği kabahatlerde kasıt olmasa bile taksirin varlığ mutlaka aranmaktaydı (Soyaslan, Genel, s.438).

${ }^{26}$ Bkz. Alacakaptan, s.26, 154; Demirtaş, s.340; Soyaslan, (Genel), s.438; Kabahatler Kanunu Tasarısının gerekçesinde kabahat nedeniyle bir haksızlığın kasten veya taksirle işlenebileceği, en azından taksire dayalı bir kusurun varlığının gerekli olduğu, ancak objektif sorumluluğun kabul edilemeyeceği belirtilmektedir (m.9). 
kabahatlerin ne anlama geldiğini bildikleri kabul edilmektedir. Bu nedenledir $\mathrm{ki}$, ihale isteklilerinin kabahatli fiilleri en azından taksirli kabahatler kapsamında de ğerlendirilmekte ve bunlara ilgili yaptırımlar uygulanmaktadır.

İhale aşamasındaki kabahatlerin manevi unsur açısından tek tek incelenmesi aşağıdaki gibidir:

Bir kişinin ihaleye fesat karıştırdığının kabulü için ihale düzenini bozucu bir davranışta bulunması ana unsurdur. $\mathrm{Bu}$ davranışlar; rüşvet, hile, vaatte bulunma, anlaşmaya yanaşma gibi fiillerden oluşmaktadır. Sırf hareket suçu niteliğindeki bu fiillerin bilerek ve isteyerek işlenmiş olması suçun oluşumu için başlı başına yeterlidir ${ }^{27}$. Bu bağlamda, kabahat suçunu oluşturan her bir fiilin işlenmesiyle birlikte kabahatin neticesi de (ihale düzeninin bozulması) meydana gelmektedir. Bu fiiller nedeniyle ihalenin iptal edilmiş olması, kabahatin neticesi anlamına gelmemektedir. Burada netice, fiilin işlenmesiyle ihale düzenin bozulmuş olmasıdır. İhale düzenini bozucu her fiil aynı zamanda ihalenin iptaline neden olmayabilir. Örneğin isteklilerden birisinin sahte belge kullanmasına rağmen ihaleyi bir başkası kazanarak söz konusu ihale normal koşullarda tamamlanmış olabilir. Bu durumda, ihale sahte belge kullanan dışında bir istekliye verilmiş ise, bunun ihalenin iptaline neden olmayacağı açıktır. Sadece sahte belge kullanan istekli bu davranışı nedeniyle ihalelerden yasaklanma yaptırımı ile karşılaşacaklardır.

İhaleye fesat karıştıran kimse, ihaleye fesat karıştırırken, aslında ihalenin iptal edilmesini amaçlamamaktadır. Aksine ihaleyi kazanarak kâr elde etme arzusundadır. Bu arzusu nedeniyledir ki, kabahati oluşturan bir fiili bilerek ve isteyerek işlemektedir. Bu fiilin işlenmesi ile birlikte ihale düzeni her durumda bozulmakta, fiili işleyenin ihaleden yasaklanması zorunlu hale gelmektedir. Failin fesat niteliği taşıyan davranışlarına rağmen ihalenin feshedilmesi sonucunu istememekte oluşu, bu kabahatin taksirle işlendiği anlamına gelmemektedir. Burada ihalenin feshedilmesi ve bunun sonucunda faile ihaleye katılmaktan yasaklanma kararı verilmesi, kabahatin hareket unsurları dışında kalan, idarî yaptırım işleminin sakatlığına ilişkin bir husustur.

İhalenin fesada uğratılması fiilinde olduğu gibi; rekabetin engellenmesi, ihale kararının etkilenmesi, sahte belge düzenlenmesi ${ }^{28}$, sahte belge kullanılması, birden fazla teklif sunulması, yasaklı olduğu halde ihaleye girilmesi gibi kabahatli fiillerin her birine ihaleden yasaklanma sonucu

\footnotetext{
${ }^{27}$ Bkz. Soyaslan, Genel, s.421

${ }^{28}$ Sahte belge düzenleme fiilinde, sahte belge düzenlemenin bir kamu harcama ihalesinde kullanılması amacıyla yapılması koşulu aranmamakla birlikte, ihaleye katılmaktan yasaklanma yaptırımı açısından bu amacın aranması zorunludur. Yoksa, sadece sahte belge düzenleme fiilinin gerçekleştiği, henüz belgenin kullanılmadığı bir durumda, ne amaçla düzenlendiği belli olmayan belge nedeniyle ihaleye katılmaktan yasaklama kararı verilmesi mümkün olmamalıdır.
} 
bağlanmaktadır. Fail bu fiilleri işlerken ihale düzenini bozduğunu bilmekte ve fiilini isteyerek gerçekleştirmektedir; ancak bu fiillerinden dolayı kendisine ihaleye katılmaktan yasaklanma yaptırımının uygulanmasını da istememektedirler. Bununla birlikte, ihalenin iptal edilebileceği ve ihaleden yasaklanabileceğini her zaman öngörebilmektedir.

İhale aşamasındaki önceki incelenen fiiller açısından sonuç böyle olmakla birlikte, sözleşme yapma isteği üzerine isteklinin sözleşmeye yanaşmamasında farklı olasılıklar doğmaktadır. Bunlardan birincisi failin (isteklinin) sözleşme yapmaya isteyerek yanaşmamasıdır. Bu durumda fail kasten sözleşme yapmamaktadır; sözleşme yapılmamasını ve böylece ihaleden yasaklanmasını fail istemektedir. Diğer bir olasılık failin istemeyerek sözleşme yapamaz hale gelmesidir. Sözleşme yapma süresinin geçirilmesi bir mücbir sebebe dayanıyorsa, kabahat gerçekleşmemektedir. $\mathrm{Bu}$ durumda mücbir sebep ihaleden yasaklanmayı önleyen, kusurluluğu kaldıran bir neden olmaktadır ${ }^{29}$. Süre, mücbir sebep sayılmayan bir nedenle de geçebilir. Bu durumda fail neticeyi istemediğinden taksirli bir davranışta bulunmuş olmaktadır. Sonuçta kamu harcama ihalelerinde ihaleye katılmaktan yasaklanma yaptırımı, kasten veya taksirli işlenebilen fiillere dayanabilmektedir. Dolayısıyla KK ile manevi unsur yönüyle bir uyum sorunu bulunmamaktadır.

Sözleşmenin uygulanması aşamasındaki kabahatlerdeki manevi unsurun değerlendirilmesinde; yüklenici edimini yerine getirirken kasitlı veya taksirli davranabilir. Ancak burada sayılan kabahatlerin de sırf hareket (suçu) niteliğinde bulunmaları nedeniyle, fiilin işlemesiyle kabahat tamamlanmaktadır. Yüklenici burada da kâr elde etme amacıyla hareket ettiğinden, kabahatinin bilinmesini ve sözleşmenin feshedilmesini istememektedir; hatta bazı kabahatleri daha fazla kâr elde etme isteğinden kaynaklanmaktadır.

\section{KABAHATİN ÖZEL OLUŞUM BİÇIMLERI}

Kabahatlerin farklı işleniş şekilleri özel görünümlerini oluşturmaktadır. Bunlar üç ana başlık altında incelenecektir: Teşebbüs, iştirak ve içtima.

\footnotetext{
${ }^{29}$ Demirtaş, s.362; Kabahatler Kanununa göre hukuka uygunluk ve kusurluluğu kaldıran TCK hükümleri idarî kabahatlere de uygulanacaktır (KK m.12). Mücbir nedenlerin KK'nda tanımı yapılmamaktadır. Bununla birlikte nelerin mücbir sebep sayılabileceği yönünde de bir belirtme yoktur. Bu durumda mücbir sebep "kamu harcama ihalesi sonucunda müteahhidin idare ile belirtilen süre içerisinde sözleşmenin imzalanamaması sonucunu doğuran, failin iradesi dışında gerçekleşen bir neden" şeklinde tanımlayabiliriz. Bu neden doğal afet olabileceği gibi, kaza, ağır hastalık gibi nedenler de olabilir. Bu bağlamda mücbir sebebin sözleşmeye etkisi, vergisel ödevlere sürelerin etkisi göz önünde bulundurulduğunda, paralel bir yorumla sözleşme yapma süresini kesen bir etki olabileceği düşünülmektedir.
} 


\section{A. TEŞEBBÜS}

KK'nunda da kural olarak kabahatlerde "teşebbüs" kabul edilmemekle birlikte kanunun açıkça belirttiği durumlar istisna tutulmaktadır (KK m.13) ${ }^{30}$. Ayrıca TCK' nun suça teşebbüs ve gönüllü vazgeçmeye ilişkin kurallarının uygulanacağını belirtmektedir (KK m.13).

Kamu harcama ihalesinde, ihale ve sözleşme aşamalarında işlenebilen kabahatlere bakıldığında üç teşebbüs hâli görülmektedir (KİK m.17; KİSK m. 25); "ihaleye fesat karıştırmaya teşebbüs edilmesi, sahte belge düzenlemeye teşebbüs edilmesi ve sahte belge kullanmaya teşebbüs edilmesi" dir. Sözleşme aşamasında da aynı teşebbüs fiilleri kabul edilmektedir (KİSK m.25). Bunların dışında bir kabahate teşebbüs idarî yaptırım sonucunu doğurmamaktadır.

Fiilin teşebbüs halinde kalması durumu da, sanki tamamlanmış gibi aynı idarî yaptırıma neden olmaktadır. Bunun teşebbüs veya gönüllü vazgeçme olmasının önemi bulunmamaktadır: her iki durumda da sonuç fesat karıştıranın ihalelerinden yasaklamasıdır. Sahte belge düzenlenmesinde veya düzenlenen bu belgelerin kullanılmasında teşebbüs hâlinin gerçekleşmesi oldukça zordur. Çünkü, sahte belge düzenlemesi ancak ihale aşamasından önce yapılabileceği için, bu belgelerin ihaleye sunulması amacıyla yapıldığının ve kullanılacağının ispatlanması zordur. Ayrıca, sahte belgenin kullanılmasına teşebbüs fiili ancak başvuru anında gerçekleşebilir. Zarfların kapalı sunulması nedeniyle zarfların açılmasından sonra, tekliflerin değerlendirilmesi aşamasında belgelerdeki sahtecilik anlaşılabilecektir ki, zaten bu durumda belge kullanılmış olmakla teşebbüs aşaması geride kalmaktadır. Dolayısıyla, sahte belgenin kamu harcama ihalesine sunulma amacıyla düzenlenmesine teşebbüs veya sahte düzenlenen belgenin kullanımına teşebbüs edilmesi fiilleriyle işlenebilecek bir kabahatin gerçekleşmesi düşük bir olasılıktır. Aynı şekilde sözleşmenin uygulanması aşamasında da idareye sunulması gereken belgelerin sahte düzenlenmesine teşebbüs edildiği veya kullanılmasına teşebbüs edilmesini kabul etmek zordur. İdareye teklifini sunan bir kişi aynı zamanda belgelerini de teklif ekinde sunmuş olduğundan, zaten belgeyi kullanmış olmakta, bu nedenle fiilin teşebbüs hali ile karşılaşılmamaktadır.

\section{B. İSTTIRAK}

Kabahatlere birden fazla kişi "iştirak" ettiğinde, her bir faile ayrı idarî yaptırım uygulanmaktadır (KK m.14/I). Kanun sadece "idarî para cezası"

\footnotetext{
${ }^{30}$ Soyaslan, (Genel), s.344; Kabahatler Kanunu Tasarısının gerekçesinde kural idarî kabahatlere teşebbüsün olamayacağıdır. Ancak, belli kabahatlere teşebbüsün cezalandırılabileceğine ilişkin kanunlardaki hükümlerin saklı olduğu belirtilmektedir (m.13).
} 
yaptırımı için, kabahate iştirak edenlere de idarî para cezası verileceğini öngörmektedir (KK m.14). Bununla birlikte doğrudan parasal bir değeri olmayan ihaleye katılmanın yasaklanmasında, yasaklanmaya neden olan davranışa iştirak etmenin nasıl gerçekleşeceği konusunda hüküm bulunmamaktadır. Burada kabahatlerde kanunilik ilkesi gereği, iştirakin açıkça kabahat sayılmaması ve bir yaptırıma bağlanmaması nedeniyle idarî bir yaptırım uygulanamayacaktır (KK m.4).

Kamu harcama ihalesine fesat karıştırma, rekabeti engelleme ve ihale kararını etkileyici davranışta bulunmak, sahte belge düzenlemek ve birden fazla teklifte bulunmak fiillerine iştirak etmek mümkün gözükmekle birlikte, sahte belgeyi ihalede kullanmak fiilline iştirak edebilmek zordur. Sahte belgeyi ihale teklifinde kullanabilecek kişi sadece ihale isteklisidir. İhaleye katılmanın yasaklanmasına neden olan fiiller karara maddî unsur olabilecek seçimlik fiillerdir. İhale sürecinde bir doküman alarak katılmamış olanlar ve doküman alanların fiillerine iştirak edenler hakkında ihaleye katılmaktan yasaklanma kararı verilememekle birlikte, eğer fiilleri TCK'nun 235 nci maddesi kapsamında değerlendirilebiliyorsa cezâ̂ anlamda suç oluşturabilecektir. Sözleşmenin uygulanması aşamasında da aynı şekilde iştirak edenlere eğer fiilleri TCK nun 236 nci maddesine göre ceza uygulanabilecektir.

\section{C. İÇTIMA}

Bir fiil ile birden fazla kabahatin işlenmiş olması durumunda bunlardan daha ağır idarî para cezasının uygulanması kabahatlerde "içtima" yı göstermektedir (KK m.15/I). İdarî para cezalarında parasal değerler belli olduğundan içtimanın uygulanabilmesi kolaydır. Ancak, idarî para cezası dışında başka bir idarî yaptırım öngörülmekte ise, bu yaptırımlardan her birinin uygulanmasına karar verilmektedir (KK m.15). Böyle bir durumda, ortak bir ceza ölçüsü olmadığından ağır olanın belirlenmesi de imkansızdır.

Burada fiilin hem kabahat hem de suç oluşturması söz konusu ise hangi yaptırım veya yaptırımlar uygulanacaktır ? Cezâ̂ bir yaptırımla idarî bir yaptırım içtima ettirilebilecek midir? Daha açık bir ifadeyle sadece idarî para cezası içeren yaptırımlar mı yoksa ihaleden yasaklanma yaptırımı da suçlar için öngörülen cezalarla içtima ettirilebilir mi? İhlâl edilen kuralların kabahat veya suç olması, içtima için önem taşımamaktadır ${ }^{31}$. Bununla birlikte KK idarî para cezalarının diğer idarî yaptırımlarla içtima ettirilemeyeceğini, her bir yaptırımın ayrı ayrı uygulanacağını da belirtmektedir (KK m.15/I, 2. cümle). Bu durumlarda bir fiilin birden fazla kabahat oluşturması ve yaptırımının da sadece birbirinden farklı tutarda idari ${ }^{31}$ İçel, Kayıhan: Suçların İçtimaı, İstanbul Üniversitesi Yayınları, İstanbul 1972, (İçel,
İçima), s. 76. 
para cezası olması durumunda, en ağır cezanın uygulanacağı açıktır. Bu bağlamda bu idarî para cezasını gerektiren kabahat dışında, işlenen fiil ayrıca suç oluşturuyorsa, sadece suça ilişkin ceza uygulanabilecektir (KK m.15/III). İdarî para cezasının diğer idarî yaptırımlarla içtima ettirilmemeleri karşısında, bu kez idarî para cezası dışında kalan yaptırımların suçların yaptırımlarıla içtima ettirilip ettirilmeyecekleri konusu bir sorun gibi gözükmektedir. Çünkü, kabahatler ile suçlar arasındaki içtima kuralı düzenlenirken, kabahatlere uygulanan idarî yaptırım türleri arasında bir ayırım yapılmamaktadır. Diğer bir ifade ile gerek kuralın deyimsel anlamında, gerekse maddenin gerekçesinde, bir fiilin hem kabahat hem de suç olarak tanımlanmasından söz edilmektedir ${ }^{32}$. Fiil her iki tanıma giriyorsa sadece suçtan dolayı ceza verilebilecektir. İhaleden yasaklanma yaptırımı ile suçlar için öngörülen hürriyeti bağlayıcı yaptırımlar nitelik bakımından farklı olmakla beraber (TCK'nun 235, 236), KK'nun idarî yaptırım türleri arasında bir fark gözetmemesi sonucu bir taraftan ihaleye veya sözleşmenin ifasına fesat karıştıranlar hürriyeti bağlayıcı ceza ile cezalandırılırlarken, diğer taraftan, ihale düzenine aykırı davranışları nedeniyle ayrıca ihaleye katılmaktan yasaklanmayacaklar ve "ne bis in idem kuralı" işleyecektir" Ancak, fail bu durumda TCK'nunda 235 ve $236 \mathrm{nc}$ maddelerdeki hürriyeti bağlayıcı cezalar yanında, ayrıca bir mahkumiyetin yasal sonucu olarak ${ }^{34}$, ihalelere katılmanın yasaklanmasının ötesinde meslek ve sanatını kendi sorumluluğu altında (tacir olarak) yapmaktan yasaklanmak gibi, gerçek kişi veya tüzel kişi olmasına göre yasanın ifadesiyle daha ağır bir "güvenlik tedbiri” ile karşılaşabilecektir (TCK m.53, 60).

İçtima konusu ile bağlantılı olabilecek bir diğer konu da, ihale süreci ve sözleşme sürecindeki kabahatlerin farklı zamanlarda işlenmiş olmalarından dolayı her fiile ayrı yaptırım uygulanması gerekeceğidir. İhale kazanan yüklenici hem ihale hem de sözleşmenin uygulanması aşamalarında ihaleden yasaklanmayı gerektiren fiillerde bulunabilir. Hatta ihale aşamasında işlenen kabahatinin sözleşmenin uygulanması aşamasında anlaşılması da mümkündür. $\mathrm{Bu}$ durumda taahhüdün ifa aşamasına göre bir uygulama söz konusu ise de, ihalenin feshine bile karar verilebilmektedir (KİSK m.21). Farklı aşamalardaki farklı kabahat fiilleri birden fazla ihaleden yasaklanma kararının verilmesi sonucunu doğurur ${ }^{35}$.

Aynı fiil nedeniyle yapılan bir ceza soruşturması kabahatin soruşturulması üzerinde ne tür bir etki yapacaktır ? Bu konu yetkili organlar kadar kullanılan usullerin ve yaptırım türlerinin de farklı olması nedeniyle özem kazanmaktadır. KK'nu yürürlüğe girmeden önce kabahatin aynı

${ }^{32}$ KK'nun 15/III maddesinde kabahatler ile suçlar arasındaki içtima kuralı, sadece suçlar arasındaki içtima kuralı ise TCK'nun 44 ncü maddesinde düzenlenmektedir.

${ }_{33}^{33}$ Bkz. Kabahatler Kanunu Tasarısı gerekçesi (m.15).

${ }^{34}$ Bkz. Donay-Kaşıkçı, s.73.

${ }^{35}$ İhale ve edimin ifası aşamasındaki eylemlerin de ayrı cezalandırılması gerekir (Bkz. Donay-Kaşıkçı, s.309). 
zamanda bir suç sayılması, bir idarî yaptırımın uygulanmasına engel olmamaktaydı ${ }^{36}$. Buna neden idarî yaptırımın başlı başına bir cezaî yaptırım olmamasıdır ${ }^{37}$. KK ile suçlar ve kabahatler arasında nitelik farkı görülmediğinden bu uygulama terk edilmektedir. Yeni kurallara göre bir kabahatin aynı zamanda suç oluşturması halinde artık kabahat başlı başına bir yaptırıma tabi tutulamamaktadır (KK m.15/III). Bununla birlikte yarg1 yollarının farklı kuralları karşısında kim, ne zaman diğer soruş̧turmanın sonuçlanmasını bekleyecektir? İdarî usul açısından konuya bakıldığında idarenin ihaleden yasaklama kararını, fiili tespit ettikten sonra belli bir sürede (kırkbeş gün) vermesi gerekmektedir. İşlemin yapılabilmesi için öngörülen süre, idare açısından süreli bir yetkiyi içermektedir. Dolayısıyla idare, ceza soruşturmasından bağımsız soruşturmasını yaparak kararını verecektir. Bu kararın kesinleşmemesi için yaptırıma muhatap olan kişinin idarî mahkemede açacağı davada yürütmeyi durdurma kararı istemesi dışında bir yolu da bulunmamaktadır. Bu yol, ancak işlemin açıkça hukuka aykırı olması ve davacının telâfisi imkansız bir zararına neden olacağının anlaşılması durumunda davacı yararına bir durum yaratabilecektir (İYUK $\mathrm{m} .27 / 2)$.

İhaleye katılmaktan yasaklanma yaptırımı, muhatabının gerçek kişi veya tüzel kişi olması durumunda farklı sonuçlar doğurmaktadır. İhaleye fesat karıştıranın gerçek kişi olması halinde fiil aynı zamanda suç oluşturmaktaysa sadece suçtan cezalandırılacaktır. Eğer ihaleye fesat karıştıran tüzel kişinin temsilcisi ise sadece tüzel kişi hakkında ihaleden yasaklama kararı verilebilecek, temsilci için ihaleye katılmaktan yasaklanma kararı verilemeyeceği için sadece suç oluşturan fiili nedeniyle cezaî sorumluluğu olabilecektir (TCK m.235). Tüzel kişiye uygulanan idarî yaptırım ile temsilcisine uygulanan cezaî yaptırımın içtiması söz konusu edilemeyecektir.

\section{VI. İDARÎ YAPTIRIM: İHALEDEN YASAKLANMA}

İdarî yaptırımlar idare tarafından bir idarî işlemle tesis edilmektedir ${ }^{38}$. İdarî yaptırımlar işlemi yapan organ, işlemin türü, işlemin niteliği ve uygulanacak usul kuralları yönüyle suçlar için öngörülen yaptırımlardan farklıdır. Genellikle suçlar için öngörülen yaptırımlar cezalandırıcı nitelikte olduğu halde, idari yaptırımlar idarî düzeni korumaya, suçun işlenmesini önlemeye yönelik ve uyarıcı nitelik taşımakta, cezaî nitelik taşımamaktadır ${ }^{39}$.

${ }^{36}$ Bkz. Demirtaş, s.58; Gözler, Kemal: İdare Hukuku, C.I, Ekin Kitabevi, Bursa 2003, s.946; Mahmutoğlu, s.137, 155; Oğurlu, s.78.

37 Zanobini, Guido: "İdarî Ceza hukukunda Kıstas Meselesi", (Çev. Dr. Yılmaz Günal), AÜSBFD, C.XVIII, Eylül-Aralık 1963, No:3-4, s.317.

${ }^{38}$ Gölcüklü, I, s.136; Günday, Metin: İdare Hukuku, İmaj Yayınc1lı, Ankara 2003, s.216; Özay, s.40.

${ }^{39}$ Bkz. Demirtaş, s.57; Donay, Süheyl: "İdarenin Ceza Verme Yetkisi Konusunda Anayasa Mahkemesinin Bir Kararı Üzerine Düşünceler”, İÜHFM, C.XXXVII, S.1-4, s. 426; 
Kabahatlere uygulanan yaptırım türleri "idarî para cezası" ve "idarî tedbir" şeklinde iki başlıkta toplanmaktadır. Bunlardan idarî tedbirler "mülkiyetin kamuya geçirilmesi" ve "ilgili kanunlarda yer alan diğer tedbirler" şeklinde belirtilmektedir ${ }^{40}$. Bu tedbirleri sayıca sınırlandırmak oldukça zordur ${ }^{41}$. Konumuz olan ihaleye katılmaktan yasaklanma yaptırımı bir idarî tedbir türüdür. Diğer bir deyişle KK'nda düzenlenmeyen, diğer kanunlarda yer alan diğer tedbirler kapsamındadır.

İhaleye katılmaktan yasaklama kararı yenilik doğurucu ve aynı zamanda yükümlendirici bir idarî işlemdir: Bu işlem kamu ekonomisinden piyasa ekonomisine doğru işleyen bir ödeneğin harcanmasına ilişkin süreçte katılımcıların haklarını etkilemektedir. Böyle bir kararın sonucunda kamu harcamasına taliplilerin ihaleye katılma hakları bir süre için ellerinden alınmaktadır. Bunun sonucunda her biri kâr elde etmek arzusunda olan katılımcılar ve hatta ihaleyi kazananlar, sağlayabilecekleri olası kârlarından mahrum kalmaktadırlar. Böylesine maddî nitelikli etkinin yanında katılımcıların yasaklanma kararından manen etkilenmemeleri de mümkün değildir. Sonuçta bu karar malî sistemin doğru işleyişini sağlayan, diğer bir ifadeyle harcama düzenini koruyan bir "malî kabahat" örneğini göstermektedir. Bu nedenle de idarî işlemin unsurlarını taşımaktadır.

İhaleye katılmaktan yasaklanma kararı, kararı veren organın olayın delilleri üzerinde bir tespit yetkisi kullanılmasını da içerir. Bu yetkinin ihale düzeninin hukuka uygun işlerliğinin sağlanmasına yönelik kullanılması zorunludur. Bu nedenle keyfilikten uzak bir bağlı yetki söz konusudur. İhaleye katılanların ihale sürecinde yaşadıkları maddî olayları, fiilleri deliller ile değerlendirilecek ve kurala uygun olup olmadığı tespit edilecektir. Dolayısıyla tespit yetkisi işlemin sebep ve konu unsuru üzerinde gerçekleşebilmektedir. Kesin bir kanaatin oluşmadığı durumlarda, ceza hukukunda olduğu gibi şüpheden katılımcının yararlanması söz konusu olacaktır $^{42}$. Tabiî ki, idare bir idarî işlem yapıyor olması nedeniyle geçerli bir gerekçeye dayanması hukuksal denetim için de önem taşımaktadır.

Günday, s.216; İçel, (İdarî Ceza), s.119; İçel-Donay, s.32; Mahmutoğlu, s.93, 128.

${ }^{40}$ Diğer kanunlarda yer alan tedbirler 1) bir meslek ve sanatın yerine getirilmemesi; 2) işyerinin kapatılması; 3) ruhsat ve ehliyetin geri alınması; 4) kara, deniz veya nakil aracının trafikten men veya seyrüseferden alıkonulması; 5) gibi yaptırımlar şeklinde sayılarak bu tür yaptırımların sınırlandırılamayacağı gösterilmektedir (KK m.16, 19). Dolayısıyla, birer idarî yaptırım olan idarî tedbirler, özel kabahat içeren kanunlardaki sayıda ve türdedir. KK ile amaçlanan, özel kanunlarda düzenlenen kabahatlerin genel kurallarının zamanla uyumlu hale getirilmesidir. Özel kabahatler bulunan kanunlarda KK'na uygun değişiklik yapılıncaya kadar kendi kurallarının uygulanmasına devam edileceği de açıktır. Kamu harcama ihalesine katılmaktan yasaklanmayı düzenleyen KİK ve KİSK da bu kapsamda değerlendirilecektir.

${ }^{41}$ Bkz. Özay, (Yaptırımlar), s.110; Kabahatler Kanunu Tasarısı gerekçesi (m.16).

${ }^{42}$ İdarî yaptırımlarda da şüpheden sanık yararlanır kuralının uygulandığına ilişkin açıklamalar için bkz. Özay, (Yaptırımlar), s.120. 
İhaleye katılmaktan yasaklanma kararı ilk etkisini kararda belirtilen süre kadar ihalelere katılamama şeklinde göstermektedir. Kabahatlerin ihale sürecindeki işleniş aşamalarına göre iki tür yasaklayıcı süre öngörülmektedir: İhale aşamasında işlenen fiiller nedeniyle verilen ihaleden yasaklama kararı bir yıldan iki yıla kadar; sözleşme yapmaya yanaşmama durumunda ise altı aydan az olmamak üzere bir yıla kadar olabilmektedir. Sözleşme aşamasında verilebilecek yasaklanma süresi bir yıldan az olmamak üzere iki yıla kadardır. İdare haksızlığın özelliğini dikkate alarak yasaklama süresini alt ve üst sınırları içerisinde kalmak koşuluyla takdir etmektedir. Sürenin takdirinde esas alınacak zaman ölçülerinde bir sınırlama bulunmadığına göre gün, hafta, ay veya yıl şeklinde belirlenebilmesi mümkün olabilecektir.

İhaleye katılmaktan yasaklama kararının ikinci etkisi, muhatabın diğer bütün kamu kuruluşlarının ihalelerine de katılmasını önlemesidir. Hatta KİK'na tâbi olmayan kamu kurum ve kuruluşlarının ihaleleri de bu kapsamdadır (KİK m.2, 3, 58/I; KİSK m.26/I). Buradan kamu ihale düzeninin bir bütün olduğu kabul edilerek ister gelir elde etmeye isterse harcama yapmaya yönelik olsun tüm ihaleleri kapsadığı anlaşılmaktadır. Kişi bakımından ihaleye katılmaktan yasaklama kararı sadece ihaleye teklif sunanlarla sınırlı değildir. İhaleye katılan isteklilerin gerçek kişi ve tüzel kişi olmasına göre, yasaklama yaptırımının başka muhatapları da olabilmektedir (KIKK m.58/II; KİSK m.26/II ${ }^{43}$. İlk olasılıkta idarî yaptırım uygulanacak kişi gerçek kişi ise, karar yalnızca bu gerçek kişi hakkında verilmektedir. Gerçek kişinin ayrıca şahıs veya sermaye şirketinin ortağı olması durumuna ilişkin olasılıklar, kararın kapsamını değiştirmekte ve genişletmektedir: Eğer kişi bir şahıs şirketinin ortağı ise, ihaleden yasaklama kararı bu şirketi de kapsamaktadır. Ortaklık payının oranının, kararın verilmesinde önemi bulunmamaktadır ${ }^{44}$. Ĕğer kişi bir sermaye şirketinin ortağı ise, ancak bu kişinin şirket sermayesinin yarısından fazlasına sahip olması durumunda, sermaye şirketi hakkında da ihaleden yasaklama kararı verilmektedir. İdarî yaptırım uygulanacak kişi bir tüzel kişi ise, yine tüzel kişinin şahıs şirketi veya sermaye şirketi olması durumuna göre farklı sonuçlar ortaya çıkmaktadır . Şahıs şirketlerinde, şahıs şirketi ile birlikte şirket ortaklarının tamamı hakkında da ihaleden yasaklama kararı verilmektedir. Sermaye şirketlerinde ise, şirket sermayesinin yarısından fazlasına sahip ortak için ihaleden yasaklama kararı verilmesi gerekmektedir. Burada müteşebbislerin gerçek kişi olması, onların başkaca ekonomik güçleri (çoğunluk payları) ile ihale düzenlerinde kârlar peşinde koşmaları önlendiği gibi, tüzel kişiler kendi çoğunluk paylarına sahip ortaklarıyla birlikte yasaklanmakta ve hatta birbirleriyle kişisel ilişkilerin ön plânda olduğu şahıs şirketlerinde ortakların hepsinin yasaklanmasına karar verilebilmektedir.

${ }^{43}$ KK'na göre organ veya temsilcinin davranışından dolayı tüzel kişiler hakkında da idarî yaptırım uygulanabilmesi öngörülmektedir (m.8).

44 Taşdelen, s.159 


\section{USUL}

Kamu harcama ihalesinde ihaleye katılmaktan yasaklanma yaptırımının usule ilişkin başlıca kuralları idarî işlemin usulüne (yetkiye, karara ve idarî soruşturmaya) ve bu işleme ilişkin yargılama usulüne (başvuru yollarına) ilişkin olabilecektir:

\section{A. İDARİ İŞLEMDE USUL}

\section{Yetki}

İhaleye katılmaktan yasaklanma kararı bir yarg1 kararına gerek duyulmadan harcama işlemine taraf olan idare tarafından ve idare hukukuna özgü usullerle verilmektedir ${ }^{45}$. İdare harcama düzeni üzerindeki sübjektif koruma hakkını kullanmakta ve bu düzenin zarar görmesini önlemektedir ${ }^{46}$. İhaleye katılmaktan yasaklama kararını vermeye "yetkili organ", idarenin Bakanlık bünyesinde bulunması durumunda ilgili Bakanlık, ilgili Bakanlığın bulunmaması durumunda idarenin "ihale yetkilisi” dir. İl özel idareleri, belediyeler ve bunlara bağlı birlik, müessese ve işletmelerin ihalelerinde idarî yaptırım kararı İçişleri Bakanlığıdır (KİK m.58/I; KİSK m.26/I).

KK'nunda idarî yaptırım kararları farklı organlar tarafından verebilmektedirler. Bu kanuna göre ana kural; kanunda açıkça gösterilen idarî kurul, makam veya kamu görevlileri ve açıklık olmayan durumda ise "en üst amir" dir (m.22). Bir istisna Cumhuriyet Savcisıdır (KK m.23). Bununla birlikte yapılmakta olan bir ceza yargılamasında fiilin suç olmayıp kabahat olduğunun anlaşılması durumunda, mahkemenin idari organlar yanında idarî yaptırım kararı verebilme yetkisi bir diğer istisnayı oluşturmaktadır (KK m.24). Bunun için öncelikle TCK nun 235 veya 236 ncı maddesine aykırılık nedeniyle kamu davasının açılmış olması ve yargılama sonucunda fiilin suç yerine kabahat olduğunun anlaşılması gerekmektedir.

KK'nda kabahatlere ilişkin "zamanaşımı süresi” sadece idarî para cezası için düzenlenmektedir. Burada "sorușturma zamanaşımı" ve "yerine getirme zamanaşımı" süreleri bakımından para cezası tutarları dikkate alınarak farklı süreler tespit edilmiştir. Diğer idarî yaptırımlar için ise bir zamanaşımı süresi öngörülmemektedir. $\mathrm{Bu}$ nedenle, kamu harcama ihalesinde ihaleye katılmaktan yasaklanma kararının tesis edileceği süre, KK'nunda düzenlenmeyen konulardan olduğu için, KİK ve KİSK'na göre belirlenecektir. Bakanlıklar veya ihale yetkilileri idarenin ihaleden yasaklama kararı gerektiren bir davranışın tespit etmeleri üzerine, tespitten itibaren en geç kırk beş gün içerisinde kararlarını vermeleri gerekmektedir

${ }^{45}$ Demirtaş, s.57; Mahmutoğlu, s.129.

${ }^{46}$ Mahmutoğlu, s.117; Zanobini, s.314-316. 
(KIK m.58/IV; KİSK m.26/IV). Burada ihaleden yasaklanmaya neden olacak fiiller nasıl tespit edilecektir? İhaleden yasaklanmayı gerektiren fiillerin ihale öncesinde veya ihale sonrasında gerçekleşmesi mümkündür. Yine, bu fiiller idare tarafından kendiliğinden fark edilebileceği gibi, ihbar üzerine de öğrenilebilecektir. Hatta, fark edilme ihale kesinleștikten sonra da olabilecektir. Burada "tespit edilme" olgusu önem taşımaktadır. Çünkü, bu andan sonra kırkbeş günlük süre hesaplanacaktır. Tespit edilme, tekliflerin değerlendirilmesi aşamasında gerçekleşirse ki, istekli bu nedenle de değerlendirilme dışı bırakılacağı için bir tespit işleminin yapıldığ 1 varsayılacaktır. Ancak, tespit işlemi için her zaman böyle bir anın bulunmadığ 1 bir gerçektir. Bu bağlamda yetkili organın hangi sürede tespite yönelik bir ön işlem yapabileceğine ilişkin açık kural da bulunmamaktadır; bir idarî usul kanununun bulunmamasından dolayı düzenleme boşluğu ile karşılaşılmaktadır. İdarenin ihbar üzerine öncelikle delilleri toplayarak olayın tespiti işlemini yapması gerekmektedir. Bundan sonra idareye işlem yapabilmesi için sınırlandıran hak düşürücü süre işleyecektir.

İdarenin işlem yapabilme süresinin kanunda gösterilmekte oluşu, bazen işlemin tarafı için güvence bazen de idarenin hızlı işlem yapması anlamına gelmektedir ${ }^{47}$. Kanunda belirtilen kırk beş günlük sürenin niteliği "en geç" ibaresi ile belirlenmektedir. Bu ifade şekli idarenin işlemini disiplin etme amacı gütmemektedir. Kuralın emredici bir özellik taşıması, yasaklama kararının muhatabı açısından bir güvence oluşturmaktadır ${ }^{48}$. İdare bu süreyi geçirdikten sonra, süre bakımından yetkisi kalmayacağı için, artık ihaleye katılmaktan yasaklanma kararı veremeyecektir. Yetkinin belirlenen sürede kullanılmaması, işlemin muhatabının yaptırıma karşı korunmasını sağlamaktadır. Süresi içinde karar verilmemesi nedeniyle görevlilerin cezaî sorumluluğu doğabilecektir. Buna ek olarak, sürenin geçirilmesi durumunda artık ortada yasaklama kararı bulunmayaca ğından, bu kişiler, sonraki ihalelere katılabilecek ve bundan rekabete dayalı kamu ihale düzeni zarar görmüş sayılmayacaktır. Aynı şekilde ihaleye katılmaktan yasaklanma kararının yerine getirilmesinde de benzer bir kural bulunmaktadır. Kararın en geç on beş gün içerisinde yayımlanmak üzere RG'ye gönderilmesi zorunludur. Burada öngörülen süre de yaptırımın muhatapları açısından güvence taşımaktadır. RG'de yayımlanarak kararın yerine getirilmesine (infazına) başlanabilecek, yani yasaklama süresinin hesaplanmasına geçilebilecektir.

\footnotetext{
${ }^{47}$ Bkz. Akyılmaz, Bahtiyar: İdarî Usul İlkeleri Işı̆̆ında İdarî İşlemin Yapılış Usulü, Yetkin Yayınları, Ankara 2000, s.113; Gözübüyük, Şeref-Tan, Turgut: İdare Hukuku, C.I, Turhan Kitabevi, Ankara 2001, s.384; Günday, s.128.

${ }^{48}$ Bkz. Kamu İhale Genel Tebliği, Birinci Bölüm, XV, s.74.
} 


\section{Karar}

İhaleye katılmaktan yasaklanma kararına ilişkin işlemler, ana hatlarıyla karar öncesindeki işlemlere, karar verme süresine, kararın içeriğine, tebliğine, başvuru yollarına ve ilânına ilişkindir. İster şikayet isterse idare kendiliğinden ihaleye katılmaktan yasaklanma nedenini öğrensin, idareler gereğinin yapılması için konuyu ilgili Bakanlığa bildirmekle yükümlüdürler (KİK m.58/son; KİSK m.26/son). Bildirimin kimin tarafından yapılacağ 1 belirlenmemiş̧ir. İhalenin sahibi olarak ihale yetkilisinin bildirimle yükümlü olması, idarî işleyişe uygun olacaktır. Yasa, ihaleye katılmaktan yasaklamayı gerektiren davranışın belirlenmesinden itibaren hangi sürede bildirimde bulunulacağını belirtilmemektedir. Görevlilerin gecikmesi cezaî bir sorumluluğa neden olabileceğinden bildirim işleminin hemen yapılması uygun olacaktır ${ }^{49}$. Herhangi bir Bakanlığa bağlı olmayan, yani ihale yetkilileri tarafından idarî yaptırım uygulanması gereken durumlarda, hukuka aykırı davranışın ihale komisyonu tarafından tespiti ile birlikte durumun ihale yetkilisine bildirilmesi gerekir.

İhaleye katılmaktan yasaklanma kararının şekli konusundaki kurallar, Genel Tebliğ'de açıklanmaktadır: İhale kayıt numarası, kararı veren idare, ihaleden yasaklama kararı verilen kişiler, kimlik bilgileri ve ihaleden yasaklanma süresi bunlar arasındadır ${ }^{50}$. KK'nda da buna benzer açıklamalara yer verilmektedir: idarî yaptırım kararının bir tutanak şeklinde düzenleneceği ve içeriğinde; yaptırım uygulanan kişinin kimlik ve adresi, kararın verilmesine neden olan fiil (işlendiği yer ve zamanı ile), fiile ilişkin deliller, karar tarihi ve kararı verenin kimliğinin bulunması gerekmektedir (KK m.24). Tüzel kişi hakkında verilecek kararda ticaret sicil kaydına uygun bilgilerin tam kullanılması (unvan ve adres açısından) bazı uyuşmazlıkları baştan önleyebilecektir.

İhaleye katılmaktan yasaklanma kararının tebliğ edilmesi ihaleye katılanların hukuksal güvenliği açısından büyük önem taşır. İdarenin aldığı karar hukuka uygun olmayabilir. Bu amaçla yapılacak bir denetim açısından karara karşı başvuru yolu, mercii ve süresinin kararda açıkça belirtilmesi gerekir. Bu bağlamda idarî makamların incelemesi dosya üzerinden gerçekleşeceği için yapılacak tebliğ , Tebligat Kanunu'na göre yapılacaktır (KİK m.65; KK m.26) ${ }^{51}$.

\footnotetext{
${ }^{49}$ Usule ilişkin açıklamaları içeren Kamu İhale Genel Tebliğinde zamanında karar alınabilmesi için idarenin gerekli özeni göstermesi ve tedbirleri alması bildirilmektedir (Kamu İhale Genel Tebliği, RG. 25886-25.07.2005).

${ }^{50}$ Kamu İhale Genel Tebliğ̣i, Birinci Bölüm, XV, s.73.

${ }^{51}$ KK'nda idarî yaptırım kararının idarî makamın huzurunda verilmesi durumunda farklı bir düzenlemeye yer verilmektedir (KK m.26/II).
} 


\section{3. İdarî Sorușturma}

İdari usul açısından kanunda isteklilerin iddia ve savunmalarının nasıl alınacağ 1 açık değildir ${ }^{52}$. Bu bağlamda, Avrupa Konseyi Bakanlar Komitesinin "Bireyin İdarî İşlemler Karşısında Korunması (77/31) hakkında tavsiye kararı uyarınca isteklilerin haklarının korunması, savunma ve delillerini sunma imkânının tanınması, idareden bilgi ve belge edinmelerinin sağlanması ve savunma için gerekli sürenin verilmesi gerekmektedir ${ }^{53}$.

\section{B. YARGILAMA USULÜ}

İdarî yaptırımlara karşı başvuru yolu genellikle idarî organlar veya yarg1 organları önündedir. Bu kararlara karşı yarg1 yolu esas olarak idarî yargı olmakla birlikte, yasada açıkça belirtilmiş durumlarda adlî yargı da olabilmektedir ${ }^{54}$. Bu bağlamda tebliğ edilmiş bir idarî yaptırım kararına karşı başvuru yollarının KK ve KİK (ve KİSK)'e göre farklı düzenlendiği görülmektedir. KK'nda "başvuru yolu" sadece idarî para cezası ve mülkiyetin kamuya geçirilmesi şeklindeki idarî yaptırımlar için geçerlidir (KK m.27). Bu iki tür idari yaptırım için başvuru kararın tefhim ve tebliğinden itibaren onbeş gün içerisinde sulh ceza mahkemesine yapılmaktadır ${ }^{55}$. İtiraz başvurusunun sulh ceza mahkemesi tarafından incelenmesi, yaptırımın idarî niteliğine etki yapmamaktadır ${ }^{56}$. Bu kanun ihaleye katılmaktan yasaklanmanın da içerisinde bulunduğu "ilgili kanunlarda yer alan diğer tedbirler" açısından bir düzenleme getirmemektedir.

İhaleye katılmaktan yasaklanma kararının bir idarî işlem olması, buna ilişkin uyuşmazlığın idarî yargıda çözümleneceğini göstermektedir. Kaldı ki, KK nun genel kurallarının tüm kabahatlere uygulanması istenmekle birlikte, diğer kanunlardaki belirli süre için yasaklanmayı öngören idarî yaptırımlara ilişkin hükümler -ki bunlara ihaleden yasaklanma yaptırımı da dahildir- bu kanuna uygun değişiklikler yapılıncaya kadar saklı tutulmaktadır (KK m.19). Böylece önceden olduğu gibi gerekli değişiklikler yapılıncaya kadar idarî yargıda uyuşmazlıklar çözümlenmeye devam edilecektir.

${ }_{52}$ İdari usul kavramı için bkz. Akyılmaz, s.70.

${ }^{53}$ Bkz. Gözübüyük-Tan, C.I, s.627; Oğurlu, s.216 vd.

${ }^{54}$ Gölcüklü, Feyyaz: "İdarî Ceza Müeyyidesi ve Bunlara Karşı Kanun Yolları", AÜSBFD, Cilt. XVIII, S.3-4, Eylül-Aralık 1963, s.191; Özay, (Yaptırımlar), s.140; Oğurlu, s.131.

${ }^{55}$ Uyuşmazlık Mahkemesi kararlarında idarî para cezası açısından KK'nun yürürlüğge girdiği 01.06.2005 tarihinden sonra açılan davaların adlî yargıda görüleceği (Hukuk Bölümü, 21.11.2005 T., 2005/92 E., 2005/112 K. RG. 28.12.2005-26037) ve davanın açıldığ tarihte görevli olan mahkemenin yeni yasa ile görevli hale gelmesi durumunda görevsizlik kararı verilmesi gerektiği, ancak yeni yasadaki görev kuralı değişikliğinin yürürlüğe girmesinden sonra açılacak davalarda uygulanacağına ilişkin geçiş kurallarının varlığ 1 halinde mahkemenin görevsizlik kararı veremeyeceği belirtilmektedir (Hukuk Bölümü, 21.11.2005 T. 2005/76 E., 2005/102 K. RG. 28.12.2005-26037).

${ }^{56}$ Donay, s.426; Oğurlu, s.139. 


\section{SONUÇ}

KİK' na tâbi idareler mal ve hizmet alımı ile yapım işlerine ilişkin alımlarını ihale düzenine göre gerçekleştirmekte ve buna dayalı sözleşmeler ile uygulamaktadırlar. İdareler ihtiyaçlarını ve uygulayacakları ihale usulünü belirledikten sonra, ihalenin koşullarını ilgililere ilân yoluyla duyurulmaktadır. İcaba davet niteliğindeki bu ilânlar üzerine kişiler ihale dokümanını satın alarak ihalede istekli olabilmek için ön adımı atmaktadırlar. Böylece yapılacak ihale düzenine katılarak, bundan sonra ihale sürecindeki kurallara uymakla yükümlenmektedirler. Bu süreç birkaç aşamadan oluşmakta, bu aşamalarda ihale dokümanı almış veya teklif de sunmuş olan ve hatta ihaleyi alarak sözleşme yapma hakkını kazanan kişi de bazı ödevlerle karşılaşmaktadır. Bu ödevlere aykırı davranışlar geniş anlamda ihale düzenine, dar anlamda da ihaleye diğer katılanların haklarına zarar vermektedir. Ödevlere uyulmaması bazen cezaî yaptırıma neden olsa da, bazen sadece idarî nitelikte (ihalelerden bir süre için yasaklanma gibi) olmaktadır. Bu malî nitelikli bir kabahate uygulanan yaptırımdır. Bu nedenle halen idarî yargıda hukuka uygunluğu denetlenmektedir.

İhaleye katılmaktan yasaklanma kararına neden olan davranışlar birçok başlık altında toplanabilirse de hepsinin ihale süreci bakımından ortak özelliği, ihale hazırlığından itibaren sözleşmenin ifasına kadarki süreçte yer almalarıdır. Bu fiillerin her biri ihale düzenini bozulabilmekte, yasa deyimiyle fesada uğramaktadır. Sayma yöntemi yerine daha kapsayıcı bir şekilde kısaca ihalenin ve ihale üzerine yapılan sözleşmenin bozulmasına neden olan her türlü davranışın kabahati oluşturacağının belirtilmesi daha uygun olacaktır.

KK' nda düzenlenen genel kuralların tüm kabahatlere uygulanacağ belirtilmekle birlikte uyum sağlanıncaya kadar Kanunda düzenlenmeyen idarî yaptırımlara ilişkin diğer kanunlardaki kurallar saklı tutulmaktadır. Dolayısıyla KİK ve KİSK'nda genel kanuna uygun düzenlemeler yapılıncaya kadar aykırı hükümler geçerliğini korumaktadır. Tabiî ki bu arada ihale düzenine aykırı davrananlar için KK' nda bulunan bazı lehe kuralların uygulanması da mümkündür: ihale düzenini ihlâl edenin ceza soruşturmasında cezalandırılmış olmasının ayrıca ihaleden yasaklanmasını önlemesi örneğinde olduğu gibi. Bu bağlamda ihale düzenine bizzat ihale dokümanı alarak ihaleye adım atmamış olanların kabahate iştirakleri yerine suça iştirakleri söz konusu olabilmektedir.

İhaleye katılmayı yasaklayan kararların alınması ve yerine getirilmesi, idarenin bozulan ihale düzenini korumayı ve haksızlıkta bulunanları belli bir süre için kamusal ihale düzeni dışında bırakmayı amaçlamaktadır. Bu yaptırımın etkinliği, idarenin yetkisini belli sürelerde kullanabilmesine bağlıdır. Sürelerin geçirilmesi ihalede haksızlık yapanlar için, tekrar ihale sürecinde yer alabilmelerinin bir güvencesini (korumasını) sağlamaktadır. 
KİK ve KİSK'nda düzenlenen ihaleye katılmaktan yasaklanma yaptırımına uygulanacak genel hükümleri açısından KK ile uyum sağlanması kaçınılmazdır. Uyum için değişikliğin KİK ve KİSK'nunda yapılması öngörülmektedir. Bununla birlikte KK'nda ihaleye katılmaktan yasaklanma yaptırımına uyumlu genel kurallara sahip olmadığı da bir gerçektir. KK'nda usul kurallarının (başvuru yolunu ve zamanaşımı süreleri gibi) sadece idarî para cezası ve mülkiyetin kamuya geçirilmesi yaptırımları açısından düzenlenmiş olması, kanunun genel niteliğine ilişkin eksikliğini açıkça göstermektedir. Değişiklikler yapılırken kamu harcamalarını düzenleyen kanunlar ile KK'nda birlikte ele alınması isabetli kuralların oluşturulmasını kolaylaştıracaktır. 


\section{KISALTMALAR}

AÜHFD. : : Ankara Üniversitesi Hukuk Fakültesi Dergisi

AÜSBFD. : : Ankara Üniversitesi Siyasal Bilgiler Fakültesi

Bkz. : : Bakınız

D. : Daire

Dan. : Danıştay

DİK. $\quad$ : Devlet İhale Kanunu

E. $\quad$ : Esas

IÜHFM. : İstanbul Üniversitesi Hukuk Fakültesi Mecmuası

K. $\quad$ : Karar

KİK. $\quad$ : Kamu İhale Kanunu

KİSK. $\quad$ : Kamu İhale Sözleşmeleri Kanunu

KK. $\quad$ : Kabahatler Kanunu

m. : Madde

Mük. $\quad$ : Mükerrer

RG. : Resmi Gazete

s. $\quad$ :Sayfa

S. $\quad$ : Say1

T. $\quad$ : Tarih

TCK. : Türk Ceza Kanunu

vd. : ve devamı 


\section{KAYNAKÇA}

Akyılmaz, Bahtiyar: İdari Usul İlkeleri Işı̆̆ında İdari İşlemin Yapılış Usulü, Yetkin Yayınları, Ankara 2000.

Alacakaptan, Uğur: Suçun Unsurları, Ankara Üniversitesi Hukuk Fakültesi Yayınları, Ankara 1970.

Artuk, Mehmet Emin-Gökcen, Ahmet-Yenidünya, A. Caner $\quad$ : $\quad$ C e z a Hukuku Özel Hükümler, Turhan Kitabevi, 6. Bası, Ankara 2005.

Demirtaş, Timur: Ceza Hukuku Genel Hükümler, Seçkin Yayınları, Ankara 2002.

Devellioğlu, Ferit: Osmanlıca-Türkçe Ansiklopedik Lûgat, Ankara 2002.

Donay, Süheyl: "İdarenin Ceza Verme Yetkisi Konusunda Anayasa Mahkemesinin Bir Kararı Üzerine Düşünceler”, İHFM, C. XXXVII, S.1-4, s.411-427.

Donay, Süheyl-Kaşıkçı, Mahmut: 5237 Sayılı Türk Ceza Kanunu, Vedat Kitapçılık, İstanbul 2004.

Gölcüklü, Feyyaz: "İdari Ceza Hukuku ve Anlamı: İdarenin Cezai Müeyyide Tatbiki”, AÜSBFD, C.XVI, No:2 Haziran 1963, (Gölcüklü, I).

Gölcüklü, Feyyaz: İdarî Ceza Müeyyidesi ve Bunlara Karşı Kanun Yolları”, AÜSBFD, C.XVIII, Aralık-Eylül, 1963 (Gölcüklü, II).

Gözler, Kemal: İdare Hukuku, C.I, II, Ekin Kitabevi, Bursa 2003.

Gözübüyük, Şeref-Tan, Turgut : İdare Hukuku, C.I, Turhan Kitabevi, Ankara 2001.

Günday, Metin: İdare Hukuku, İmaj Yayıncılık, Ankara 2003.

Hafızoğulları, Zeki: Ceza Normu, Normatif Bir Yapı Olarak Ceza Hukuku Düzeni,Us-A Yayıncılık Limited Şirketi, 2. Baskı, Ankara 1996.

İçel, Kayıhan: "İdari Ceza Hukuku ve Kabahatleri Suç Olmaktan Çıkarma Eğilimi”, İÜHFM, C.50, S.1-4, s.117-131, İstanbul 1984, (İdarî Ceza).

İçel, Kayıhan: Suçların İçtimaı, İstanbul Üniversitesi Yayınları, İstanbul 1972, (İçel, İçtima).

İçel, Kayıhan- Donay, Süheyl: Karşılaştırmalı ve Uygulamalı Ceza Hukuku, Genel Kısım, 1. Kitap, 4. Bası, Beta Basım Yayım Dağıtım A.Ş., İstanbul 2005.

İçel, Kayıhan-Sokulu-Akıncı, Füsun-Özgenç, İzzet-Sözüer, AdemMahmutoğlu, Fatih Selami-Ünver, Yener : Suç Teorisi, Beta Basım Yayım Dağıtım A.Ş., 2. Bası, İstanbul 2000 (İçel, Suç Teorisi). 
Küçükgüngör, Erkan-Akipek, Şebnem: "Kamu İhale Sözleşmeleri”, Malî Hukuk, Y1l 8, 2003, S.103.

Mahmutoğlu, Fatih Selami: Kabahatleri Suç Olmaktan Çıkarma Eğilimi ve Düzene Aykırılıklar Hukukunda (İdari Ceza Hukukunda) Yaptırım Rejimi, Kazancı Kitap Ticaret A.Ş., İstanbul, 1995.

Özay, İl Han: İdarî Yaptırımlar, İstanbul Üniversitesi Yayınları, İstanbul 1985 (Özay, Yaptırımlar).

Özay, İl Han: Gün Işı̆̆ında Yönetim, Alfa Yayınları, İstanbul 2002 (Özay, Yönetim)

Soyaslan, Doğan: Teşebbüs Suçu, Kazancı Kitap Ticaret A.Ş., İstanbul 1994 (Soyaslan, Teşebbüs).

Soyaslan, Doğan: Ceza Hukuku Genel Hükümler, Yetkin Yayınları, 2.Baskı, Ankara 2003, (Soyaslan, Genel).

Taşdelen, Aziz: Kamu Harcamaları Hukukunda İhale Süreci, Turhan Kitabevi, Ankara 2004.

Türk Dil Kurumu: Türkçe Sözlük, C.I, Ankara 1998.

Zanobini, Guido: “İdarî Ceza Hukukunda Kıstas Meselesi”, (Çev. Dr. Yılmaz Günal), AÜSBFD, C. XVIII, Eylül-Aralık 1963, No: 3-4, s.301318. 